\title{
Pemanfaatan Radio untuk Mengatasi Keterbatasan Jaringan pada Pembelajaran Daring Selama Masa Pandemi
}

\author{
Amin Mustajab *1, Tri Syamsijulianto², Mohammad Zaky Tatsar ${ }^{3}$, Rian Priyadi ${ }^{4}$ \\ 1,2 Sekolah Tinggi Keguruan dan Ilmu Pendidikan Melawi, Jl. Lintas Malindo, Entikong, Indonesia \\ ${ }^{3}$ Madrasah Aliyah Al-Maarif Singosari, Jl. Ronggolawe No. 07, Malang, Indonesia \\ ${ }^{4}$ Sekolah Menengah Atas Negeri 4 Batang Hari, Jl. Lintas Jambi - Ma. Bungo KM 104, Jambi, Indonesia \\ *email: aminmustajab53@gmail.com¹, syamsijulianto17@gmail.com², zakytatsar1000@gmail.com³ \\ rianpriyadi94@gmail.com 4
}

\begin{abstract}
During the Covid-19 epidemic, learning had to be carried out online. Internet-based online learning cannot be carried out in remote areas that have difficulty accessing internet networks such as the Entikong border area. On the other hand, learning must be carried out so that other solutions for online learning activities are needed. Community Service Program (PKM) with online learning using radio media is carried out in collaboration with RRI Pro-1 Entikong. This program is carried out in view of the limitations of internet network access in the Entikong and surrounding sub-districts. The results of the PKM activities carried out could cover $70 \%$ of Entikong and surrounding areas which have limitations in accessing the internet. In addition, online learning using radio media can also work well, this is evidenced by 95\% of the questions asked are in line with the learning submitted.
\end{abstract}

Keywords: Radio Utilization, Online Learning, Pandemic

\begin{abstract}
Abstrak
Masa pademi Covid-19 mengakibatkan pembelajaran harus dilaksanakan secara daring. Pembalajaran daring berbasis internet tidak dapat dilaksanakan di daerah terpencil yang sulit mengakses jaringan internet seperti didaerah perbatasan Entikong. Dilain pihak, pembelajaran harus tetap dilaksanakan sehingga di perlukan solusi lain kegiatan pembelajaran daring. Program pengabdian Kepada Masyarakat (PKM) dengan pembelajaran daring menggunakan media radio dilaksanakan dengan bekerja sama dengan RRI Pro-1 Entikong. Program ini dilaksanakan mengingat keterbatasan akses jaringan internet pada wilayah kecamatan Entikong dan sekitarnya. Hasil dari kegiatan PKM yang dilaksanakan dapat mencakup 70\% wilayah Entikong dan sekitarnya yang memiliki keterbatasan dalam mengakses internet. Selain itu, pembelajaran daring menggunakan media radio juga dapat berjalan dengan baik hal ini dibuktikan dengan 95\% pertanyaan yang diajukan sudah sejalan dengan materi pembelajaran yang disampaikan.
\end{abstract}

Kata kunci: Pemanfaatan Radio, Pembelajaran Daring, Pandemi

\section{PENDAHULUAN}

Pandemi Covid-19 memberikan dampak besar pada berbagai bidang, salah satunya bidang pendidikan. Dunia pendidikan juga ikut merasakan dampaknya (Solviana, 2020). Aktivitas yang melibatkan kumpulan orang-orang kini mulai dibatasi seperti kegiatan belajar mengajar di sekolah, bekerja, beribadah dan lain sebagainya. Pemerintah sudah menghimbau untuk bekerja, belajar, dan beribadah dari rumah untuk menekan angka pasien yang terpapar Covid-19 (Dewi, 2020). Penyebaran pandemi virus corona di Indonesia membuat sekolah menghentikan proses pembelajaran tatap muka yang biasa dilakukan di sekolah. Pendidik harus memastikan kegiatan pembelajaran tetap berjalan, meskipun peserta didik berada di rumah (Arifin, 2020). Seorang pendidik dituntut untuk memiliki kompetensi agar dapat memahami dan mampu menggunakan teknologi digital serta penerapannya (Khusniyah \& Hakim, 2019).

Perkembangan teknologi informasi dan komunikasi pada era sekarang ini menunjukkan semakin banyak media yang beredar di masyarakat (Daulay et al., 2020; Priyadi, 2019). Keberadaan teknologi bagi dunia pendidikan merupakan sarana yang dapat dipakai sebagai media penyampaian program pembelajaran baik secara searah maupun secara interaktif, proses belajar tidak lagi dibatasi oleh ruang kelas tertentu. Selain itu, penggunaan teknologi telah 
memungkinkan munculnya pembelajaran jarak jauh dan mendorong inovasi yang lebih besar dalam menciptakan metode pengajaran di dalam dan di luar kelas (Fitriyani et al., 2020).

Pembelajaran daring merupakan sebuah inovasi pendidikan yang melibatkan unsur teknologi informasi dalam pembelajaran. Hingga saat ini media yang sering digunakan adalah media berbasis komputer dan internet yang dilakukan secara daring (Syahfitri et al., 2020). Pembelajaran daring dapat dijadikan solusi pembelajaran jarak jauh ketika terjadi bencana alam, seperti yang terjadi ketika pemerintah menetapkan kebijakan social distancing (Syarifudin, 2020). Proses belajar mengajar sangat menentukan hasil belajar yang akan dicapai oleh siswa (Sihombing, 2018). Oleh karena itu, kebijakan dan implementasi daring sebaiknya memperhatikan aspek siswa, guru, sarana pendukung, materi, evaluasi, interaksi, platform teknologi yang digunakan, dan sistem manajemen pembelajaran (Nurkolis \& Muhdi, 2020).

Pembelajaran daring saat ini dijadikan solusi dalam masa pandemic Covid-19. Namun, pembelajaran daring tidak semudah seperti yang dibayangkan (Dewi, 2020). Banyak kendala yang dialami ketika pembelajaran daring dipilih menjadi bentuk pembelajaran pengganti tatap muka. Mulai dari keterbatasan signal dan ketersediaan gawai pada setiap siswa. Hal ini dikarenakan lokasi rumah siswa jauh dari akses internet dan tidak semua siswa berasal dari keluarga mampu (Syarifudin, 2020). Adanya pembelajaran daring justru dianggap menjadi beban bagi sebagian siswa dan orang tua. Bagi siswa dan orang tua yang belum pernah mengenal gawai akan kebingungan dan akhirnya tidak menyelesaikan tugas yang disampaikan oleh guru (Dewi, 2020). Permasalahan ini juga dialami di kecamatan Entikong.

Entikong merupakan salah satu kecamatan di Kabupaten Sanggau. Kecamatan Entikong berbatasan langsung dengan Negara Malaysia sehingga menjadikan kecamatan Entikong sebagai beranda Negara Indonesia. Kondisi geografi kecamatan Entikong yang berada pada daerah perbukitan, menyulitkan untuk penyedia layanan telekomunikasi untuk menyediakan akses internet di daerah yang terdapat pada kecamatan Entikong. Keterbatasan akses transportasi juga memberikan tantangan tersendiri bagi siswa untuk mengakses daerah yang terjangkau fasilitas internet. Untuk mengatasi kendala teknis pembelajaran daring berbasis internet di daerah perbatasan, pendidik dapat bekerja sama dengan media massa sebagai solusi lain agar pembelajaran dapat tetap berjalan.

Dalam era informasi, media massa merupakan salah satu sumber belajar yang sangat diperlukan bagi profesi guru, dosen, atau penyuluh pertanian. Media massa menjadi penting karena merupakan media yang aktual dan sesuai dengan perkembangan yang terjadi di masyarakat (Anwas, 2012). Radio merupakan media penyampaian informasi (Abdillah, 2020) dengan pemanfaatan gelombang elektromagnetik bebas yang memiliki frekuensi kurang dari 300GHz (panjang gelombang lebih besar dari $1 \mathrm{~mm}$ ) (Nurwulan \& Paputungan, 2009). Secara umum dapat dipahami bahwa radio dalam kehidupan sehari-hari sebagai sarana dalam penyampaian pesan kepada masyarakat (Nasor, 2017). Indonesia memiliki pengalaman dalam pemanfaatan radio untuk pendidikan yaitu dengan dikembangkannya Siaran Radio Pendidikan (SRP) sejak tahun 1951 yang ditujukan untuk mantan pelajar pejuang kemerdekaan. Tahun 1977 dikembangkan SRP untuk membantu kegiatan penataran guru sekolah dasar. Program ini diprioritaskan bagi guru-guru di daerah terpencil (Anwas, 2012). Pengalaman penggunaan radio sebagai media pembelajaran dapat kita gunakan sebagai solusi lain pembelajaran daring selama masa pandemi untuk menjangkau daerah terpencil yang tidak memiliki jaringan internet.

\section{METODE}

Pembelajaran menggunakan media radio ini dilakukan dengan melibatkan Radio Republik Indonesia (RRI) Pro-1 Entikong pada saluran 100,7 FM. Lama waktu pembelajaran menggunakan media radio 1 jam (60 menit). Kegiatan program pembelajaran mengunakan media radio dilakukan dengan tiga sesi. Sesi pertama, berupa penyampaian materi oleh pendidik. Sesi kedua, 
merupakan sesi menjawab pertanyaan dari para pendengar melalui pesan singkat. Sesi ketiga, merupakan sesi penutup.

Pada sesi pertama pendidik akan mengulas matri pelajaran dengan melakukan siaran secara langsung melalui siaran RRI Pro-1 Entikong. Sesi pertama berlangsung selama 25 menit. Pengabdi diberi kesempatan untuk menyampaikan materi pelajaran sesuai dengan materi pelajaran yang sudah terjadwal. Di akhir sesi pertama pengabdi mempersilahkan para pendengar untuk menyampaikan pertanyaan kepada pendidik terkait materi yang disampaikan.

Pada sesi kedua, pendidik menjawab pertanyaan yang diajukan oleh pendengar. Sesi kedua di berikan waktu selama 20 menit. Pada sesi ini digunakan ntuk mengukur apakah pembelajaran menggunakan radio ini sudah berjalan dengan baik. Indikator dari pembelajaran berjalan dengan baik adalah sejalannya pertanyaan yang diajukan oleh pendengar.

Pada sesi ketiga, merupakan sesi penutup. Pada sesi penutup diberikan waktu selama 5 menit. Sesi ketiga digunakan pengabdi untuk memberikan kesimpulan terhadap pembelajaran yang telah dilakukan. Sisi ketiga juga digunakan untuk membeerikan pengerahan terhadap pembelajaran berikutnyaa.

\section{HASIL DAN PEMBAHASAN}

Program pembelajaran daring dengan menggunakan media radio yang dilaksanakan terrealisasi sebanyak lima kali pertemuan. Program pembelajaran dilaksanakan dengan bekerja sama dengan RRI Pro 1 Entikong. Program pembelajaran daring dimulai pada minggu keempat bulan April hingga minggu kedua bulan Mei (Tabel 1) .Dari total 75 pendengar yang bertanya, 70\% merupakan pendengar yang berda pada daerah yang tidak memiliki akses internet.

Tabel 1. Jadwal program pembelajaran daring menggunakan media radio

\begin{tabular}{|c|c|c|c|c|}
\hline No & Tangal & Nama Guru & Materi & $\begin{array}{c}\text { Waktu } \\
\text { Pelaksanaan }\end{array}$ \\
\hline 1 & 27 April 2020 & Amin Mustajab, M.Pd. & Usaha dan Energi & 10.00-11.00 WIB \\
\hline 2 & 30 April 2020 & Tri Syamsijulyanto, M.Pd & $\begin{array}{l}\text { Ekologi dan Lingkungan } \\
\text { Hidup }\end{array}$ & 10.00-11.00 WIB \\
\hline 3 & 8 Mei 2020 & Amin Mustajab, M.Pd. & Daya & 10.00-11.00 WIB \\
\hline 4 & 14 Mei 2020 & Amin Mustajab, M.Pd. & $\begin{array}{l}\text { Impuls dan Momentum } \\
\text { Linear }\end{array}$ & 10.00-11.00 WIB \\
\hline 5 & 19 Mei 2020 & Tri Syamsijulyanto, M.Pd & $\begin{array}{l}\text { Pengelolaan dan Masalah } \\
\text { Lingkungan Hidup }\end{array}$ & 10.00-11.00 WIB \\
\hline
\end{tabular}

Materi pembelajaran yang disampaiakan merupakan materi pembelajaran IPA dan fisika. Materi pembelajaran fisika terdiri dari usaha dan energi, daya serta impuls dan momentum linear. Materi pembelajaran IPA terdiri dari ekologi dan lingkungan hidup serta pengelolaan masalah dan lingkungan.

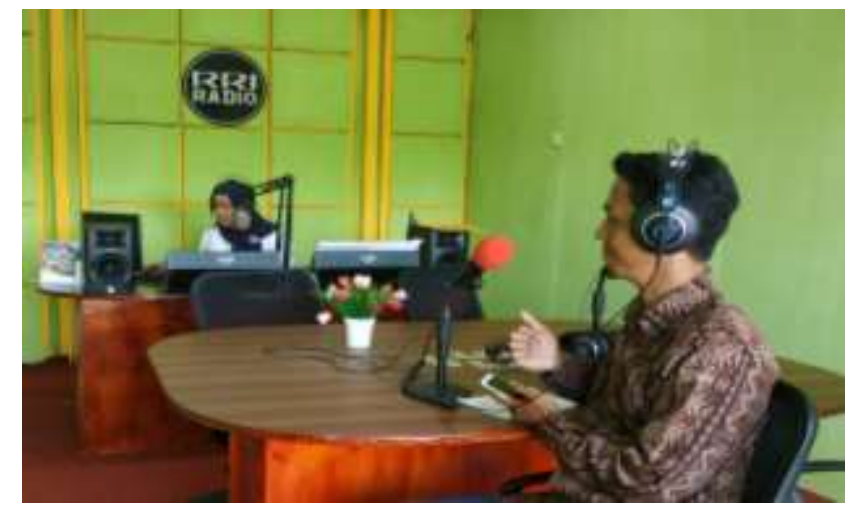

Gambar 1. Siaran langsung pembelajaran daring menggunakan media radio di RRI Pro 1 Entikong 
Sesi pertama pada setiap program pembelajaran daring menggunakan media radio diisi dengan penjabaran materi pembelajaran dipandu oleh tim penyiar dari RRI Pro 1 Entikong. Tujuan dari pemandu siaran ini agar penyampaian materi pembelajran tidak monoton atau satu arah sehingga pendengar tertarik dan tidak merasa bosan. Penyampaian materi pembelajaran berlangsung selama 25 menit. Sesi pertama ini diakhiri dengan mempersilahkan pendengar untuk mengajukan pertanyaan atas meteri yang telah disampaikan. Terdapat jeda 5 menit sebeleum di lanjutkan pada sesi kedua. Pelaksanaan program pembelajaran daring menggunakan media radio dapat dilihat pada Gambar 1.

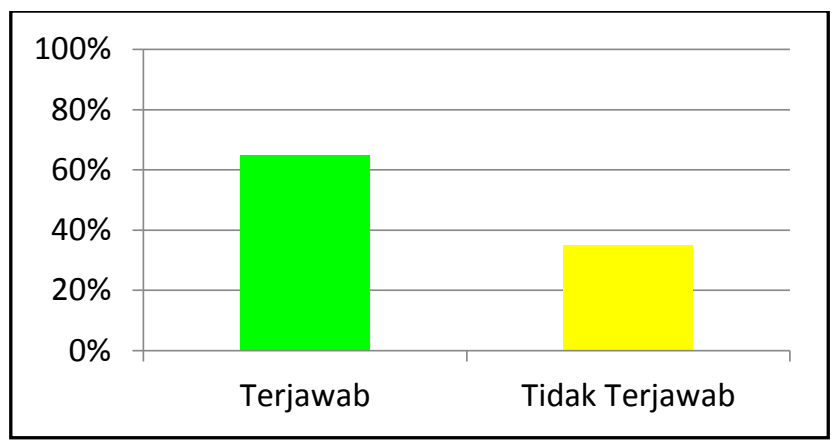

Gambar 2. Persentase Keterjawaban Pertanyaan.

Sesi kedua dilaksanakan setelah jeda dari sesi pertama. Tujuan pemberian jeda ini untuk memberikan kesempatan bagi pendengar untuk menyampaikan pertanyaan melalui media pesan singkat maupun melalui sambungan telepon. Pada sesi kedua, berlangsung selama 20 menit. Rerata jumlah pendengar yang mengajukan pertanyaan sebanyak 15 orang. Dari rarata pertanyaan yang diajukan pendidik hanya dapat menjawab $65 \%$ yang diajukan sementara $35 \%$ tidak dapat terjawab. Dari rerata pertanyaan yang diajukan 95\% sudah sejalan dengan materi yang disampaikan, $5 \%$ pertanyaan yang diajukan dari pendengar tidak berkaitan dengan materi yang disampaikan (Gambar 3). Sesi kedua diakhiri dengan jeda selama 5 menit.

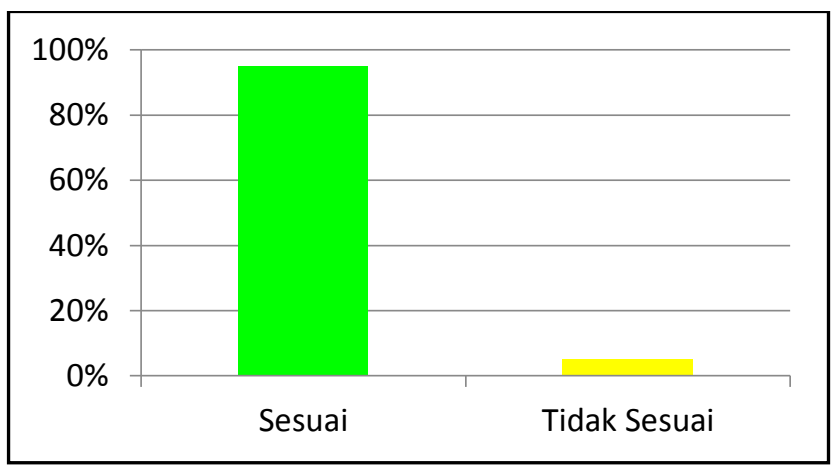

Gambar 3. Persentase Kesesuaian Pertanyaan.

Sesi ketiga merupakan sesi penutup. Sesi penutup berlangsung selama 5 menit. Pendidik menyampaikan kesimpulan dari pembelajaran yang telah dilakukan. Pada sesi penutup pendidik juga menyampaiakan pesan singkat terhadap pentingnya langkah pencegahan penyebaran COVID-19.

Program pembelajaran daring menggunakan media radio yang dilaksanakan selama lima kali pertemuan, dinilai mampu dijadikan sebagai solusi lain atas pembelajaran daring berbasis inernet. Hal ini dapat dilihat dari persentase kesesuaian pertanyaan yang diajukan mencapai 95\%. Kesesuaian pertanyaan ini menjadi indikator bahwa materi pembelajaran yang disampaian dapat didengar oleh para pendengar. Program pembelajaran daring menggunakan radio ini juga dinilai berhasil menjangkau daerah-daerah terpencil, hal ini dibuktikan dari data para pendengar yang mengajukan pertanyaan $70 \%$ bersal dari daerah yang tidak terjangkau oleh sinyal internet (Gambar 4). 


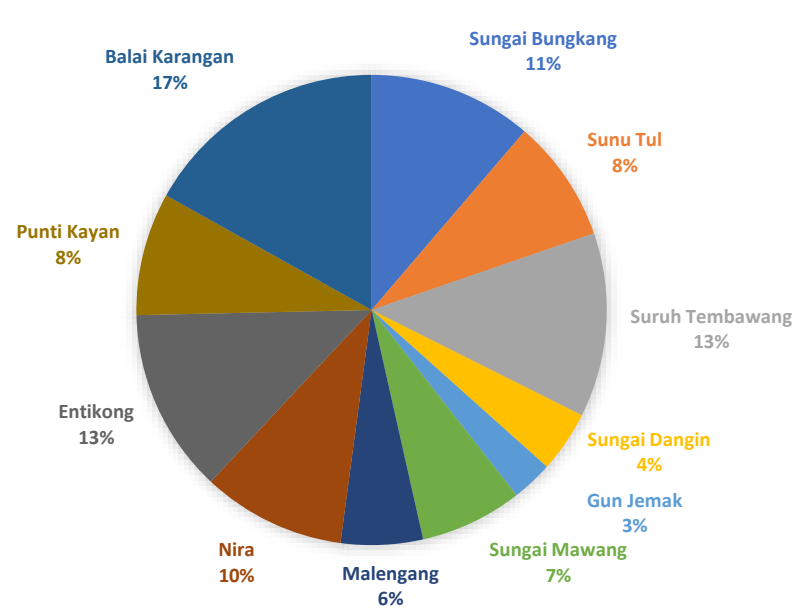

Gambar 4. Persentase Sebaran Wilayah Penanya.

Program pembelajaran daring menggunakan radio dapat menjangkau daerah-daerah terpencil yang memiliki keterbatasan akses internet. Program pembelajaran daring menggunakan radio memberikan kesempatan bagi para pendengar, terutama para siswa yang berada pada daerah terpencil untuk dapat mendapatkan pelayanan pendidikan. Hal ini dapat membatu siswa yang berada di daerah untuk mengejar ketertinggalan dalam mengakses pendidikan.

Pada sesi kedua, terdapat rerata 35\% dari pertanyaan yang diajukan oleh pendengar belum bisa terjawab hal ini disebabkan karena terbatasnya waktu siaran. Hal ini juga menjadi indikator tersendiri bahwa minat para pendengar terhadap siaran yang terkait dengan pendidikan tergolong baik. Dari beberapa pertanyaan yang diajukan oleh pendengar terkait dengan ketidak jelasan penyampaian materi yang terkait dengan penggunaan rumus. Sehingga program pembelajaran daring yang dirancang menggunakan radio sebaiknya penyampaian materi lebih diutamakan untuk menyapaikan konsep dari materi tersebut. Hal ini untuk menghindari kesalahan serta kekeliruan pendengar dalam memaknai rumus yang disampaikan.

\section{KESIMPULAN}

Hasil dari kegiatan pengabdian kepada masyaakat pembelajaran daring dengan media radio ini dapat digunakan sebagai solusi lain pembelajaran daring dimasa pandemi. pembelajaran daring dengan menggunakan media radio dapat mengakses $90 \%$ wilayah pendengar yang tidak memiliki jarigan internet. Pembelajaran daring menggunakan media radio memberikan kesempatan bagi siswa di daerah terpencil untuk mendapatkan akses pendidikan selama masa pandemi. Selain itu, minat pendengar terhadap siaran pembelajaran ini baik sekali.

Terdapat beberapa keterbatasan program pembelajaran daring menggunakan media radio. Pertama pendengar akan kesulitan materi yang disampaikan jika berupa persamaan, karena keterbatasan radio dalam memvisualisasikan. Kedua keterbatasan waktu untuk menjawab pertanyaan yang diajukan oleh pendengar. Sehingga kedepannya kegiatan pengabdian harus mendesain materi yang mudah dipahami oleh pendengar.

\section{DAFTAR PUSTAKA}

Abdillah, B. P. (2020). Pemanfaatan Radio Sebagai Media Informasi Dan Hiburan Bagi Narapidana Di Lembaga Pemasyarakatan Kelas IIB Slawi. Jurnal Riset Manajemen Dan Bisnis Dewantara (JMD), 3(1), 22-31. https://doi.org/10.26533/JMD.V3I1.526

Anwas, O. M. (2012). Faktor-Faktor yang Mempengaruhi Pemanfaatan Media Massa Sebagai Media Pembelajaran. Jurnal Teknodik, 16(3), 323-337. https://doi.org/10.32550/TEKNODIK.V0I0.33

Arifin, H. N. (2020). Respon Siswa Terhadap Pembelajaran dalam Jaringan Masa Pandemi COVID- 
19 di Madrasah Aliyah Al-Amin Tabanan. Widya Balina, 5(9), 1-12. https://journal.staidenpasar.ac.id/index.php/wb/article/view/47

Daulay, R. S., Pulungan, H., Noviana, A., \& Hurhaliza, S. (2020). Manfaat Teknologi Smartphone dalam kegiatan Pembelajaran Pendidikan Islam Di Masa Pandemi Corona-19. Al-Ulum: Jurnal Pendidikan Islam, 1(1). https://doi.org/10.30596/AL-ULUM.V1I1.7

Dewi, W. A. F. (2020). Dampak COVID-19 terhadap Implementasi Pembelajaran Daring di Sekolah Dasar. EDUKATIF: Jurnal Ilmu Pendidikan, 2(1), 55-61. https://doi.org/10.31004/edukatif.v2i1.89

Fitriyani, Y., Fauzi, I., \& Sari, M. Z. (2020). Motivasi Belajar Mahasiswa Pada Pembelajaran Daring Selama Pandemik Covid-19. Jurnal Kependidikan: Jurnal Hasil Penelitian Dan Kajian Kepustakaan Di Bidang Pendidikan, Pengajaran Dan Pembelajaran, 6(2), 165. https://doi.org/10.33394/jk.v6i2.2654

Khusniyah, N. L., \& Hakim, L. (2019). Efektivitas Pembelajaran Berbasis Daring: Sebuah Bukti pada Ppembelajaran Bahasa Inggris. Jurnal Tatsqif, 17(1), 19-33. https://doi.org/10.20414/jtq.v17i1.667

Nasor, M. (2017). Optimalisasi Fungsi Radio sebagai Media Dakwah. Al-Adyan: Jurnal Studi Lintas Agama, 12(1), 105-128. https://doi.org/10.24042/AJSLA.V12I1.1447

Nurkolis, N., \& Muhdi, M. (2020). Keefektivan Kebijakan E-Learning berbasis Sosial Media pada PAUD di Masa Pandemi Covid-19. Jurnal Obsesi : Jurnal Pendidikan Anak Usia Dini, 5(1), 212. https://doi.org/10.31004/obsesi.v5i1.535

Nurwulan, A. I., \& Paputungan, I. V. (2009). Perancangan Radio Streaming Edukasi (Studi Kasus Balai Pengembangan Media Radio Yogyakarta). Seminar Nasional Aplikasi Teknologi Informasi. https://journal.uii.ac.id/Snati/article/viewFile/952/919

Priyadi, R. (2019). Desain Kuis Pembelajaran Fisika Berbasis Teknologi pada Materi Hukum Gravitasi Universal. Jurnal Riset Dan Kajian Pendidikan Fisika, 6(1), 1-4. https://doi.org/10.12928/jrkpf.v6i1.11845

Sihombing, L. (2018). Upaya Meningkatkan Motivasi Belajar PKN Siswa Kelas VII.4 melalui Penerapan Model Pembelajaran Kooperatif dengan Teknik Keliling Kelas Di SMP Negeri 21 Pekanbaru. Dinamisia: Jurnal Pengabdian Kepada Masyarakat, 2(1), 84-90. https://doi.org/10.31849/dinamisia.v2i1.1095

Solviana, M. D. (2020). Pemanfaatan Teknologi Pendidikan di Masa Pandemi Covid-19: Penggunaan Gamifikasi Daring di Universitas Muhammadiyah Pringsewu Lampung. Al Jahiz: Journal of Biology Education Research, 1(1), 1-14. http://ejournal.metrouniv.ac.id/index.php/Al-Jahiz/article/view/2082

Syahfitri, R., Sari, D. P., Wahyuni, A., Fatimah, S., \& Setiawan, H. R. (2020). Implementasi E-Learning pada Mata Pelajaran Pendidikan Agama Islam di Masa Pandemi Covid-19. Al-Ulum Jurnal Pendidikan Islam, I(1), 44-54. https://doi.org/10.30596/al-ulum.v1i1.5

Syarifudin, A. S. (2020). Impelementasi Pembelajaran Daring untuk Meningkatkan Mutu Pendidikan Sebagai Dampak Diterapkannya Social Distancing. Jurnal Pendidikan Bahasa Dan Sastra Indonesia Metalingua, 5(1), 31-34. https://doi.org/10.21107/metalingua.v5i1.7072 